\title{
Rhetorical continuity and shifts in war messages: George H.W. Bush and George W. Bush on Iraq
}

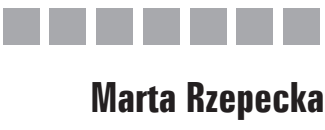

UNIVERSITY OF RZESZÓW, POLAND

DOI: 10.19195/1899-5101.10.2(19).5

\begin{abstract}
This article focuses on rhetorical continuity and shifts in the use of the genre of American war rhetoric. Drawing on Lloyd Bitzer's understanding of the rhetorical situation, the article analyses the political circumstances in which George H. W. Bush in 1991 and George W. Bush in 2002 constructed and delivered their messages. It then examines and compares the addresses for particular typologies of war rhetoric as defined by Karlyn Kohrs Campbell and Kathleen Hall Jamieson and by Edward J. Lordan. With the rhetorical elements identified, the article discusses the implications of the adherence to and departures from the genre's criteria for presidential war discourse.
\end{abstract}

KEYWORDS: war, rhetoric, Gulf War, Iraq War, George H.W. Bush, George W. Bush.

\section{INTRODUCTION}

Two areas of research are relevant to this study. Firstly, the existing literature regarding the genre of presidential war rhetoric is reviewed to highlight the recurrent elements central to the American convention of presidential war rhetoric. Secondly, the studies regarding President George W. Bush's Iraq war rhetoric are reviewed to indicate which questions regarding the president's war discourse have attracted the most scholarly attention.

Scholars in the field of rhetorical studies have presented several typologies designed to capture the nature of presidential war rhetoric. Karlyn Kohrs Campbell and Kathleen Hall Jamieson (1990) offer five characteristics of presidential war messages: (1) thoughtful consideration; (2) narration of events; (3) a call to unanimity and dedication; (4) legitimation of the role of the commander-in-chief; and (5) strategic misrepresentations. James Benjamin (1991) suggests that presidential war messages have at least two functions: (1) historical outline of the justification for war; and (2) a description of the president's aims and objectives. Edward J. Lordan (2010) advances the predictability of presidential war statements by identifying six 
interrelated themes: (1) self-protection; (2) the enemy as the aggressor; (3) Just War Theory; (4) moral superiority; (5) the inevitability of conflict; (6) and guaranteed victory; and persuasive tools: (1) argument structure; (2) fear tactics; (3) techniques used to reinforce the good intentions and morality of the message; (4) simplification; and (5) a shift in emphasis.

Research on Bush's war rhetoric pays little attention to whether the tradition of the genre applies to the president's war discourse. Studies focusing on Bush's war rhetoric suggest that researchers have focused on three questions in particular: First, how public support for the Iraq War was encouraged (Hill et al., 2010; Kerton-Johnson, 2008; Belanger, 2005; Schubert et al., 2002), how the language to sell the war was constructed (Cartledge et al., 2015; Bartolucci, 2012; Maggio, 2007; Smith, 2005), and how the accuracy and legitimacy of the rationale for the war pushed through the war agenda, facilitated media support, and drove military action (Oddo, 2011; Coe, 2011; Esch, 2010; Fisher, 2010; Kellner, 2007; Pfiffner, 2004).

A considerable amount of literature examines Bush's war discourse in a comparative perspective. Concentrating on the language that promotes war, Justin Rex (2011) contrasts Bush's impact on the agenda for the Iraq War with McKinley's influence on setting the agenda for the Spanish-American War. John Oddo (2011) weighs the president's language to push for the war in Iraq against Franklin D. Roosevelt's linguistic strategies and thematic formations used to win support for the US entering World War II. Focusing on presidential interaction patterns, Gary R. Hess (2006) compares George W. Bush's congressional-executive exchange over war making in 2002 with George H.W. Bush's attempts to seek congressional resolutions authorizing the use of force in 1991. Carol Winkler (2007) contrasts the communication of Bush with the public on the questions of invading Iraq with Ronald Reagan's efforts to win public support for the bombing of Libya. Antonio Lambino (2011) juxtaposes Bush's statements justifying continued American engagement in Iraq with McKinley's and Theodore Roosevelt's messages arguing for sustained military commitment in the Philippines. Similarly, Louis Fisher (2010) compares the justifications made by Bush for initiating military action against Iraq with claims for the use of force made by his predecessors: James K. Polk before the Mexican-American War, Abraham Lincoln before the Civil War, William McKinley before the Spanish-American War, Woodrow Wilson before World War I, Roosevelt before World War II, Harry S. Truman before the Korean War, Lyndon B. Johnson before the Vietnam War, and Ronald Reagan before the Iran-Contra Affair.

What appears to be missing from the literature is a comparative study of the war rhetoric of George W. Bush and George H.W. Bush. This article fills this gap by juxtaposing the two presidents' war rhetoric as exemplified in an Address to the Nation on Iraq delivered on 7 October 2002 in Cincinnati, Ohio, and a Radio Address to the Nation on the Persian Gulf Crisis from 5 January 1991. There are three primary goals of the article: 
- To identify parallels and differences between the rhetorical situations calling for war rhetoric against Iraq in 2002 and in 1991.

- To determine whether the second President Bush's rhetoric complied with or undermined the conventions of war discourse.

- To ascertain the political implications of the rhetorical continuity of or shifts in the generic tradition.

The discussion attempts to provide answers to the following questions: What were the constituent parts of the rhetorical situation in 2002 and how were they similar to or different from the exigencies, audiences, and constraints in 1991? Which persuasive tools dominated in the second President Bush's discourse? Was the second President Bush's rhetoric a departure or a continuation of the first President Bush's language? Finally, did the components demonstrate stability or change in the use of the genre? In the pages that follow, this article argues that despite compelling situational differences between the Persian Gulf War and the Iraq War, the presidents used comparable war language. It is suggested that the second President Bush adhered to the generic convention. While the constituent parts of his rhetorical situation were different, the basic components of his war messages remained largely the same.

The article traces shifts and continuity in the use of the genre in three phases. Firstly, it analyses the rhetorical situations in which presidential rhetoric was constructed and delivered. It examines the circumstances that necessitated military operations, the nature of US ultimatums to Iraq, the grounds for the use of force, and the scale of support provided by the Uniteded Nations, the US Congress, and the American public to reveal the shifts in the circumstances leading to military action. Secondly, the article contrasts the war messages of both presidents for particular typologies of war rhetoric as defined by Campbell and Jamieson (1990) and Lordan (2010). It measures the speeches against the genre's themes of thoughtful consideration, narration of events, a call to unanimity and dedication, legitimation of the role of the commander-in-chief, and strategic misrepresentations, as well as against conventional argument structure, fear tactics, and techniques used to reinforce the good intentions and morality of the message to reflect rhetorical continuity in presidential war discourse. Thirdly, the article discusses the implications of the adherence to and departures from the genre's criteria for presidential war discourse. It suggests that presidential war messages will most likely depend on the promoted perception of a future conflict, following the same basic framework and components but offering more substantial grounding.

\section{BACKGROUND}

Based on Lloyd Bitzer's (1968, pp. 6-8) definition, the rhetorical situation is understood as "a complex of persons, events, objects, and relations presenting an actual or potential exigence which can be completely or partially removed if discourse, introduced into the situation, can so constrain human decision or action 
as to bring about the significant modification of the exigence". Bitzer describes the exigence as "an imperfection (...) a defect, an obstacle, something waiting to be done, a thing which is other than it should be". He limits the audience to "those persons who are capable of being influenced by discourse and of being mediators of change." He refers to constraints as "persons, events, objects, and relations which are parts of the situation because they have the power to constrain decision and action needed to modify the exigence". Building on Bitzer's definition, Martin J. Medhurst (1996, pp. xv-xvi) explains that "the exigence is the engine that drives the rhetorical action - the part of the situation that is in need of remedy or resolution (...) To understand the exigence or exigences is to know what called the discourse into being in the first place". He defines the audience as "the final arbiter of persuasion or influence", and the constraints as "factors that impinge on actors in the rhetorical situation (...) are as complex as the realities of everyday life (...) and (...) are constantly changing”.

An analysis of the circumstances that necessitated respective presidential speeches announcing military operations in Iraq in 1991 and in 2002 has shown that the situations calling for the presidents' messages differed in many aspects. In the case of the Persian Gulf War, the question was whether to confront Saddam Hussein; while in the case of the Iraq War, the question was how to do it. Although the first President Bush acted in reaction to Iraq's invasion of Kuwait, he was not sure if force was necessary and weighed up the options (Bush \& Scowcroft, 1998). The second President Bush acted in the absence of an attack situation, yet he considered looking into and choosing a military option for regime change in the country (Bamford, 2004; Clarke, 2004; Suskind, 2004). The nature of the ultimatums delivered to Iraq communicates the difference in the perceived necessity to use force (Hess, 2006). The ultimatum given in the case of the Persian Gulf War was issued forty-seven days before the launch of a full-scale coalition attack, reflecting the first President Bush's readiness to wait for non-military means to work. In the case of the Iraq War, however, the ultimatum was given forty-eight hours before the US military invasion, suggesting the second President Bush's insistence on choosing a military solution. The underlying bases for the use of force were also different. In 1991, the principal reason for authorizing the use of force was the liberation of Kuwait. Military action was launched to respond to Iraq's invasion, end its occupation of the territory, and restore Kuwait's government. While the rationales for the Iraq War restated some of the points made in 1991, they focused on Iraq's possession of weapons of mass destruction and its ties to terrorist organizations. Authorization of the use of force was based on the information provided by US intelligence agencies that Iraq possessed and had the ability to deliver chemical, biological, and nuclear weapons and had links to al-Qaeda and the terrorist attacks of 9/11.

To receive congressional support for resolutions, which granted the president the authority to wage war, the first President Bush had to work with Congress 
controlled by Democrats skeptical of the imperative of the use of force. The second president Bush, however, received uncritical support of a Republican Congress and the leaders of both parties, which made his campaign for war easier (Hess, 2006; Brands, 2004). Although both presidents argued that congressional approval did not affect their war-making authority, they both took steps to secure it. The distribution of votes in the respective Congresses reflects the difference in the presidents' partisan struggle. On 14 January 1991, narrow majorities gave the first President Bush the power to go to war -250 votes in favor and 183 against in the House, and 52 in favor and 47 against in the Senate. On 16 October 2002, however, the approval in both chambers was more explicit - 296 in favor and 113 against in the House, and 77 in favor and 23 against in the Senate.

When seeking United Nations support for resolutions authorizing the use of force, the situation was just the opposite (Hess, 2006). The first President Bush held a strategic advantage in dealing with the UN. On 29 November 1990, he received uncritical support from the Security Council with 12 votes in favor of the invasion, two against, and one abstaining. Prior to the war authorization resolution, the United Nations Security Council condemned the Iraqi invasion of Kuwait, demanded a withdrawal of Iraqi troops from the territory, and placed comprehensive economic sanctions on Iraq. When Hussein failed to comply with his international obligations, 34 countries joined the US-led invasion against Iraq. The second President Bush fell short of winning an unequivocal UN Security Council resolution authorizing military action and broad international support. While the UN Security Council unanimously passed a resolution on 8 November 2002 that offered Iraq a final chance to comply with its disarmament obligations and warning of serious consequences as a result of its continued violations of its obligations, it did not debate or vote on a resolution explicitly authorizing the use of force. Members of the UN Security Council were divided over the plans to invade Iraq, with France and Germany arguing for continued non-military measures. The international support for the war was limited too, with only four coalition states contributing their forces to the invasion.

While US actions were not contingent on UN support, going to war with coalition forces clearly strengthened the first President Bush's case against Iraq. Polls conducted shortly after the Iraqi invasion of Kuwait showed that a majority of Americans opposed the United States' taking military steps against the Iraqis by $51 \%$ to $37 \%$. When the November UN resolution was passed, however, polls showed a 16-point rise in public support, with $53 \%$ of Americans in favour of the United States going to war and 40\% against. By contrast, in the case of the Iraq War, polls showed a rise in support for the war despite the lack of a UN resolution. While public approval generally stayed at over $50 \%$ since the $9 / 11$ attacks, shortly before the invasion it rose to $64 \%$ for the war to $33 \%$ against it. A majority of Americans said they would still approve of the invasion even if the UN decided not to join it. 


\section{FINDINGS}

As defined by Campbell and Jamieson, war rhetoric is discourse "in which presidents seek to justify to the Congress and to the citizenry their exercise of war powers" (1990; p. 101). It is designed to seek or strengthen support from the US Congress and the American public either before or soon after the beginning of military operations. The genre is used to prove that force is the only appropriate response to the threat. Its narrative form details events that lead to the existence of the threat and its exhortative tone calls the public to unite. War rhetoric seeks congressional approval for assumption of war powers and uses misrepresentation of events to suppress opposition and ensure sustained support from Congress and the public for action.

These criteria hold for the 7 October 2002 address. The convention of the genre of war rhetoric requires that the decision to go to war "be presented as the outcome of thoughtful consideration" and that it "be made on rational, not emotional, grounds" (Campbell \& Jamieson, 1990, p. 105). The language of the president's speech reflects rational deliberation: "Knowing these realities, America must not ignore the threat gathering against us". "Understanding the threats of our time, knowing the designs and deceptions of the Iraqi regime, we have every reason to assume the worst, and we have an urgent duty to prevent the worst from occurring". The argument for rational decision-making is reinforced by the assurance that issues related to "the nature of the threat" and "the urgency of action" were "discussed broadly and fully".

The speech justifies going to war in a dramatic narrative form and persuades that the existence of a threat necessitates the use of force despite efforts to find alternative means to eliminate it. "While there are many dangers in the world", Bush explained, "the threat from Iraq stands alone because it gathers the most serious dangers of our age in one place". Identifying the threat with the Iraqi regime, he urged that the Iraqi leader "must not be permitted to threaten America and the world with horrible poisons and diseases and gases and atomic weapons". An assurance that all possibilities have been attempted to eliminate the threat, including "containment, sanctions, inspections, even selected military action", is followed by an assertion that the danger and its consequences persist: "opponents have been decapitated, wives and mothers of political opponents have been systematically raped as a method of intimidation, and political prisoners have been forced to watch their own children being tortured".

Because confrontation of the threat demands unanimity and commitment, the exhortative tone of the speech constitutes an audience as a united and dedicated community. "We are resolved today to confront every threat, from any source, that could bring sudden terror and suffering to America", Bush proclaimed. "We did not ask for this present challenge, but we accept it. Like other generations of Americans, we will meet the responsibility of defending human liberty against violence and aggression". Appealing to the members of Congress, he said that they were "nearing an 
historic vote" and called them to "fully consider the facts and their duties". He then developed an argument for the United Nations when he said that congressional resolution would show that "America speaks with one voice and is determined to make the demands of the civilized world mean something".

The narrative and arguments it presents lay the groundwork for the "approval of presidential assumption of the office of commander in chief" (Campbell \& Jamieson, 1990, p. 112). The rhetoric that legitimates the role compels the president not only to make a detailed case for war but also to present conditions that require a swift reaction. "Failure to act", Bush explained, "would embolden other tyrants, allow terrorists access to new weapons and new resources, and make blackmail a permanent feature of world events". Addressing the critics of the war, he expressed the urgency of action even more explicitly: "Some have argued we should wait, and that's an option. In my view, it's the riskiest of all options, because the longer we wait, the stronger and bolder Saddam Hussein will become".

In presenting the conditions calling for a quick response, the tendency is to misrepresent events "in ways that stifle dissent and arouse the 'war temper' of Congress and the public" (Campbell \& Jamieson, 1990, p. 122). Available evidence proves that Bush misled Congress and the American public about Saddam Hussein and an al-Qaeda link and Iraq's possession and ability to deliver chemical, biological, and nuclear weapons (Pfiffner, 2004; Kellner, 2007). In the speech Bush said that "Iraq and Al Qaeda have had high-level contacts," that Iraq "provided safe haven to terrorists", and "trained Al Qaeda members in bomb-making and poisons and deadly gases". But a UN investigation showed that there was no link between al-Qaeda and Saddam Hussein (Pfiffner, 2004). He said that the regime "possesses and produces chemical and biological weapons" and that it "has attempted to purchase highstrength aluminum tubes and other equipment needed for gas centrifuges, which are used to enrich uranium for nuclear weapons". Yet, the evidence upon which the claims that Iraq was reconstituting its nuclear programme and had chemical and biological warfare capacity was not found (Pfiffner, 2004). He said that "Iraq has a growing fleet of manned and unmanned aerial vehicles that could be used to disperse chemical or biological weapons across broad areas" and that it "is exploring ways of using these UAVs for missions targeting the United States". Again, no proof that the aircraft was constructed to carry chemical or biological warfare agents was produced (Pfiffner, 2004).

Beyond the genre's themes, the speech exemplifies conventional tools, as identified by Lordan (2010), primarily an analysis and evaluation of arguments for the war, supported by appeals to fear and morality with its determination to achieve ultimate goals. The speech applies some of the same rhetorical techniques used by the first President Bush in the address made a decade earlier. The case for war is built on a thesis that is the most important statement and the pretext for everything that follows. In the speech opening line, Bush states: “Tonight I want to take a few minutes to discuss a grave threat to peace and America's determination to lead the 
world in confronting that threat". Arguments are structured in dichotomous terms. An assertion that "We know that Iraq and the Al Qaeda terrorist network share a common enemy - the United States of America" portrays the conflict as a confrontation, in which the United States represents the force for good, acts out of necessity, and in defense of its own and/or its allies' interests, while the enemy is the force for evil, chooses to go to war, and provokes a conflict. The emphasis is on the ultimate goals of the struggle, detracting attention away from the means and immediate, tangible negative effects and focusing on the long-term, desired ends: security of the nation, protection of its freedom, and help to others to find freedom of their own.

While, in many ways, the speech reproduces the framework and components of the 1991 speech, some variations in the use of the rhetorical forms and techniques can be observed. The speech is anchored in an assumption about a potential threat and the language that frames the hypothesis lacks decisiveness. Predictions and speculations that "Iraq could create instability and make the situation worse" or that "it could have a nuclear weapon in less than a year" communicate a lack of certainty. This does not appear to be the case for the 1991 speech, which presents its thesis firmly: "1990 saw Iraq invade and occupy Kuwait. Nineteen ninety-one will see Iraq withdraw”.

The speech puts forward presumptive UN requirements that would have to be fulfilled to avoid war without setting a deadline for Iraq to meet them. General threats that "Saddam Hussein must disarm himself, or for the sake of peace, we will lead a coalition to disarm him" or "if we allow [Iraq to develop a nuclear weapon] (...) a terrible line would be crossed" contrast with the 1991 uncompromising demands and time limit: "Eleven days from today, Saddam Hussein will either have met the United Nations deadline for a full and unconditional withdrawal" or "face the terrible consequences".

The narrative draws on consistent arguments and clear logic but it does not present any credible evidence for the claims it makes. Recurring statements arguing that "satellite photographs reveal that Iraq is rebuilding facilities at sites that have been part of its nuclear program in the past" or "surveillance photos reveal that the regime is rebuilding facilities that it had used to produce chemical and biological weapons" serve to compensate for publicly unavailable reliable sources or data. By contrast, the 1991 account rests on solid ground. The Iraqi invasion of Kuwait was a fact, in reaction to which "The United Nations, with the full support of the United States, has already tried to peacefully pressure Iraq out of Kuwait, implementing economic sanctions and securing the condemnation of the world in the form of no less than 12 resolutions of the U.N. Security Council".

Both speeches act on fear appeals. They link the feeling of fear to, and seem designed to invoke, a sense of urgency to take action. The themes of fear and time reinforce each other and lead to the critical, logical conclusion that the threat is imminent and steps must be taken without due delay. Their perspective is different, however. The 1991 speech discusses the present costs of Hussein's regime, including 
"higher oil prices", "lower growth", and "fear, suffering, and terror for the people of Kuwait", while the 2002 speech constructs scenarios that are likely to unfold in the future: "military conflict could be difficult. An Iraqi regime faced with its own demise may attempt cruel and desperate measures".

Both speeches build their credibility on the good intentions and morality of the speaker but they differ in the approach. Appeals made in the 2002 speech are based on convictions and lack the influence of a personal war experience shared in the 1991 speech. A declaration that the president is "not willing to stake one American life on trusting Saddam Hussein" or that he is "convinced that [the hope that Saddam does not give weapons to terrorists or develop a nuclear weapon to blackmail the world] is a hope against all evidence" do not have the persuasive power of a recollection of a World War II veteran: "I've seen the hideous face of war and counted the costs of conflict in friends lost" or a promise that "There will be no more Vietnams" made by an experienced congressman and the former ambassador to the United Nations.

In demonizing and dehumanizing the enemy, the 2002 speech expands the conceptualization of the enemy to a system of rule: "The threat comes from Iraq. It arises directly from the Iraqi regime's own actions - its history of aggression and its drive toward an arsenal of terror". In the 1991 speech, however, the conceptualization of the enemy is contracted to an individual: "Saddam already poses a strategic threat (...) Each day that passes increases Saddam's worldwide threat to democracy". As a result, statements that "America is a friend to the people of Iraq" and that its "demands are directed only at the regime that enslaves them", which differentiate between the people of the enemy's nation and the enemy's ruling system, appear only in the 2002 speech.

Finally, citations of third-party support are more common in the 2002 speech. References to US presidents, a UN official, and an international organization outnumber one mention of support coming from the ruler of Kuwait made in the 1991 speech.

\section{CONCLUSIONS}

Much of the existing research represents Bush's war rhetoric as consistent with the criteria of the genre of war discourse followed by earlier wartime presidents. Studies illustrate Bush's similar choice of tools in the attempt to sell the war against Iraq to the public (Oddo, 2011). Strategic misrepresentation is in the center of scholarly attention. Researchers trace the continuity of the war rhetoric convention focusing on the president's falsification, fabrication, distortion, and exaggeration of facts and evidence (Fisher, 2010). They argue for the president's compliance with the genre's criterion despite differences in exigences and constraints of his rhetorical situation. Critics of the US military intervention in Iraq draw analogies between the Iraq War and the Vietnam War, symbolizing US military failure, while supporters of Bush's 
policies in Iraq compare the War on Terror to the Cold War, a symbol of US success (Lambino, 2011).

The findings of this analysis match and complement those observed in earlier studies. They indicate that Bush's war rhetoric was a continuation of, and not a departure from, the genre of war discourse. Textual evidence suggests that the president followed the generic convention despite different situational exigencies and constraints. The analysis demonstrates that he not only strategically misrepresented his case to discourage objection to and win approval for unilateral action but also presented his decision to attack Iraq as the result of thoughtful consideration and careful deliberation within his administration. He developed arguments and laid out evidence that supported the claims that Iraq had links to al-Qaeda and the terrorist attacks of $9 / 11$ and possessed and had the ability to deliver chemical, biological, and nuclear weapons. In building his case for war, Bush called the public to commit to the cause of the elimination of the threat posed by Iraq and sought congressional support to assume the office of the commander-in-chief.

Explaining the consistency in the presidents' use of the basic components of war rhetoric, Campbell and Jamieson (1990, p. 125) posit that "the essential elements of presidential war rhetoric persist because its functions (...) persist". Given the case of the Iraq War rhetoric, a suggestion can be made that the formula remained relatively unchanged despite the change of the functions it was originally designed to fulfill. In its conventional form, war rhetoric was designed to gather support for a response to an attack. As the Iraq War was a preemptive war that started in the absence of an aggressor's attack, the goal of the discourse was to persuade the public and Congress to legitimate presidential use of war powers for a preemptive response to an adversary's potential attack. Campbell and Jamieson (1990, p. 125) maintain that the formula recasts "the events leading to military intervention as aggressive acts by an implacable enemy" but in the case of the Iraq War, there was no invasion and no single identifiable enemy. The formula worked even though no act of violence was carried out and no one specific, aggressive adversary was identified. Campbell and Jamieson (1990, p. 125) hold that "the narratives characteristics of earlier rhetoric efforts (...) are easily adapted to simplify and dramatize events" but the account of events leading to the Iraq War was complicated and the evidence presented in support of the claims made was at least questionable. The war was about many things and was to achieve many objectives. There were many questions why America was invading Iraq and what America was trying to do. Ultimately, the war was largely the initiative of the US. The UN Security Council refused to support it and congressional approval did not include a formal declaration of war.

The analysis also demonstrates that, in many aspects, Bush's rhetoric against Iraq in 2002 reflected that of his father's discourse constructed a decade earlier. The role of the thesis, the structure of the arguments, and the emphasis on the ultimate goals remained largely the same. The rhetorical forms and techniques to present them were different. Bush's rhetoric lacked the certainty and decisiveness of the 
language of his father. His message did not carry the credibility and genuineness of the 1991 speech. It expanded the conceptualization of the enemy and relied heavily on third-party support.

Discussing the rhetorical continuity and shifts in presidential war rhetoric, Lordan (2010, p. 11) states that "In the history of the United States, leaders, disputes, and military capabilities have all changed dramatically, but the basic framework and components of presidential war rhetoric have remained largely the same". While this study corroborates the idea of stability in the use of the genre, it also finds departures from the generic tradition. The analysis of the Iraq War rhetoric in the light of the Persian Gulf War discourse demonstrates that a political speech making a case for war does not need to be built on solid ground. An assumption or a speculation about a perceived threat or danger can be a convincing argument for the use of force. Preemption constitutes a new approach for handling enemies. Explicit and precise objectives are replaced with broad and ambiguous goals, and general language substitutes detailed explanations. Threats do not appear designed to create real pressure on the enemy but rather encourage noncompliance, which could then be used as an alleged reason for war. Unilateral action by the United States is made more acceptable when national security is at stake.

Consistent arguments and clear logic serve their purpose, even if they are not substantiated with verifiable proof which could confirm the truth of the assertions made. A projected sequence of events and predictions of the consequences, if acts of aggression were to be committed by the enemy, work to support the idea that the decision to go to war is dictated by emotions rather than cool calculation. Relevant knowledge needed to make an informed choice whether to go to war is subject to modification as the information to which only the president is privy can challenge the framing of the threat and the legitimacy of the steps to be taken to confront it. The strategies of tapping into the prevailing fears and intensifying the feelings associated with those fears dominate the discourse. Lack of wisdom gained from what the president had encountered and had undergone before he took office does not lead to a loss of credibility. Claims of the president's endeavours suffice to convincingly demonstrate and help to significantly strengthen his integrity. The enemy need not be a single individual in order to serve its purpose of posing a real and tangible threat. It can be conceptualized which recontextualizes the war from that against a specifically designated individual to that against a regime, lifting it beyond politics to the ground of a struggle about values.

One of the questions that emerges from these findings is whether the speech set a rhetorical precedent and whether it will invite other presidents to follow its formula. Research shows that one president's handling of a war influences another president's behaviour and discourse during a crisis. In 1991, lessons were drawn from the Vietnam War, just as were those in 2002 from the Persian Gulf War (Hess, 2006). While the exact impact of the management of the Iraq War on presidential performance will be possible to determine only after the US decides to go to war 
again, two suggestions can already be offered. If the promoted perception of a future conflict is that of an issue - thus requiring the president to shape the way in which Americans think about it - then predictably presidential rhetoric will echo the tone of the Iraq War discourse. If, however, the conflict is seen as a condition, presidential war rhetoric will comply with the traditional expectations of the genre of war discourse. Considering the criticism and cynicism that the second Bush's rhetoric has already produced, presidential statements, claims, evidence, and information will most likely be treated with more caution and care. Greater transparency of foreign policy goals and accountability for the means used to achieve them will be required to make a compelling case for a war and win congressional and public acceptance for it. Informal manipulation of the war-making process and claims for ultimate war-making authority are likely to continue but exceeding presidential authority in the interest of national security and carrying out presidential war agendas through legislation might be made harder.

\section{REFERENCES}

Bamford, J. (2004). A Pretext for War: 9/11, Iraq, and the Abuse of America's Intelligence Agencies. New York: Free Press.

Bartolucci, V. (2012). Terrorism rhetoric under the Bush Administration. Discourses and effects. Journal of Language and Politics, 11(4), pp. 562-582.

Belanger, P.W. (2005). Language and War: The Rhetoric of George W. Bush. Young Scholars in Writing: Undergraduate Research in Writing and Rhetoric, 3, pp. 24-29.

Benjamin, J. (1991). Rhetoric and the Performative Act of Declaring War. Presidential Studies Quarterly, 32, pp. 73-84.

Bitzer, L. (1968). The Rhetorical Situation. Philosophy and Rhetoric, 1, pp. 1-14.

Brands, H.W. (2004). George Bush and the Gulf War of 1991. Presidential Studies Quarterly, 34(1), pp. 113-131.

Bush, G.H.W. (1991). Radio Address to the Nation on the Persian GulfCrisis. January 5, 1991. Retrieved March 15, 2016 from http://www.presidency.ucsb.edu/ws/index.php?pid=19193\&st=\&st1=.

Bush, G.H.W., Scowcroft, B. (1998). A World Transformed. New York: Knopf.

Bush, G.W. (2002). Address to the Nation on Iraq From Cincinnati, Ohio. October 7, 2002. Retrieved March 15, 2016 from http://www.presidency.ucsb.edu/ws/index.php?pid=73139\&st=\&stl=.

Campbell, K.K., Jamieson, K.H. (1990). Deeds done in words: Presidential rhetoric and the genres of governance. Chicago: University of Chicago Press.

Cartledge, S.M., Bowman-Grieve, L., Palasinski, M. (2015). The Mechanisms of Moral Disengagement in George W. Bush's 'War on Terror' Rhetoric. The Qualitative Report, 20(11), pp. 1905-1921.

Clarke, R.A. (2004). Against All Enemies. New York: Free Press.

Coe, K. (2011). George W. Bush, Television News, and Rationales for the Iraq War. Journal of Broadcasting \& Electronic Media, 55(3), pp. 307-324.

Esch, J. (2010). Legitimizing the 'War on Terror': Political Myth in Official-Level Rhetoric. Political Psychology, 31(3), pp. 357-391.

Fisher, L. (2010). When Wars Begin: Misleading Statements by Presidents. Presidential Studies Quarterly, 40(1), pp. 171-184. 
Gallup. (2001). Americans Believe U.S. Participation in Gulf War a Decade Ago Worthwhile. Retrieved March 15, 2016 from http://www.gallup.com/poll/1963/americans-believe-us-participation-gulfwar-decade-ago-worthwhile.aspx.

Gallup. (2003). Public Support for Iraq Invasion Inches Upward. Retrieved March 15, 2016 from http:// www.gallup.com/poll/7990/public-support-iraq-invasion-inches-upward.aspx.

Hess, G.R. (2006). Presidents and the Congressional War Resolutions of 1991 and 2002. Political Science Quarterly, 121(1), pp. 93-118.

Hill, J., Oliver, W.M., Marion, N.E. (2010). 'Shaping History' or 'Riding the Wave'?: President Bush's Influence on the Public Opinion of Terrorism, Homeland Security, \& Crime. Journal of Criminal Justice, 38(5), pp. 896-902.

Kellner, D. (2007). Bushspeak and the Politics of Lying: Presidential Rhetoric in the 'War on Terror.' Presidential Studies Quarterly, 37(4), pp. 622-645.

Kerton-Johnson, N. (2008). Justifying the use of force in a post-9/11 world. International Affairs, 84(5), pp. 991-1007.

Lambino, A. (2011). The War Extension Rhetoric: An Analogic Criticism of U.S. Presidential Rhetoric During the Iraq and Philippine-American Wars. A Journal of Communication, Media, and Society, 8(1), pp. 21-34.

Lordan, E.J. (2010). The case for combat: How presidents persuade Americans to go to war. Santa Barbara: Praeger.

Maggio, J. (2007). The Presidential Rhetoric of Terror: The (Re)Creation of Reality Immediately after 9/11. Politics \& Policy, 35(4), pp. 810-835.

Medhurst, M.J. (1996). A tale of two constructs: The rhetorical presidency versus presidential rhetoric. In: Medhurst, M.J. (ed.), Beyond the rhetorical presidency. College Station: Texas A\&M University Press.

Oddo, J. (2011). War legitimation discourse: Representing 'Us' and 'Them' in four US presidential addresses. Discourse \& Society, 22(3), pp. 287-314.

Pfiffner, J.P. (2004). Did President Bush Mislead the Country in His Arguments for War with Iraq? Presidential Studies Quarterly, 34(1), pp. 25-46.

Rex, J. (2011). The President's War Agenda: A Rhetorical View. Presidential Studies Quarterly, 41(1), pp. 93-118.

Schubert, J.N., Stewart, P.A., Curran, M.A. (2002). A Defining Presidential Moment: $9 / 11$ and the Rally Effect. Political Psychology, 23(3), pp. 559-583.

Smith, C.A. (2005). President Bush's Enthymeme of Evil. The Amalgamation of 9/11, Iraq, and Moral Values. American Behavioral Scientist, 49(1), pp. 32-47.

Suskind, R. (2004). The Price of Loyalty. New York: Simon \& Schuster.

Winkler, C. (2007). Parallels in Preemptive War Rhetoric: Reagan on Libya; Bush 43 on Iraq. Rhetoric \& Public Affairs, 10(2), pp. 303-334. 